a department with a heavy teaching load, he has taught systematic and practical courses of bacteriology for medical, dental, veterinary and science undergraduate students and in the diploma courses for public health and tropical medicine and other postgraduate classes. $\mathrm{He}$ has been largely responsible for the development of the Honours School in Microbiology in Edinburgh. His early research work during and after the Second World War was on the use and mode of action of penicillin, and he made the acute observation in 1946 that penicillin probably acted directly on the cell wall. Later, he did excellent work on the modes of spread of respiratory infections and their control by air disinfection, ete. More recently, he has worked in the field of bacterial cytology and physiology, using electron microscopy and other methods to investigate the structure and function of bacterial capsules, inclusions, fimbriæe and non-fimbrial adhesive factors. $\mathrm{He}$ is an assistant editor of the Journal of Pathology and Bacteriology.

Pharmacy at London :

Prof. W. H. Linnell

Prof. Wilfred H. LinNell retired from the position of dean of the School of Pharmacy, University of London, on November 1. A native of Cheshire and educated at Stockport Grammar School, Prof. Linnell has very strong ties with the north-eastern part of Britain, where, in Newcastle upon Tyne, he served his four-year apprenticeship in a pharmaceutical business. He joined the School of Pharmacy, in London, as a student in 1914 and obtained his fellowship of the Pharmaceutical Society (together with the Society's Silver Medal) in 1916. Within five weeks he was in France with the Special Brigade, Royal Engineers. After demobilization he returned to Newcastle, as a student of chemistry at King's College, where he obtained an honours degree and was Johnson Fellow and Prizeman in 1921. The award, in 1922, of the Earl Grey Memorial Fellowship took him to Lincoln College, Oxford, where he studied with W. H. Perkin. But local patriotism guided him back to Durham, where he gained his Ph.D. in 1924 . After a short period at the Fuel Research Station, East Greenwich, he joined the School of Pharmacy in 1926, where the University of London had just instituted a degree in pharmacy. Prof. Linnell took charge of the Chemistry Department, in which he was appointed reader in 1927, and professor of pharmaceutical chemistry in 1944 . On the retirement of Prof. H. Berry in 1956, Linnell became part-time dean of the School and supervised its transference from the old premises in Bloomsbury Square to the modern building in Brunswick Square. He remained part-time dean until his retirement from the chair in 1961, when he became full-time dean of the School. Since 1926 Prof. Linnell has been prominent in all pharmaceutical affairs. He has been examiner to the Pharmaceutical Society for Statutory Examinations since 1927, a member of the Revision Committee of the British Pharmaceutical Codex and a member of the British Pharmacopoeia Commission Committee.

Dr. F. Hartley

Dr. Frank Hartlety, who succeeds Prof. W. H. Linnell, entered pharmacy in 1929, under the old 'oral and practical conditions', and after Part 1 continued his studies for the pharmaceutical chemist examination with an intercollegiate course at University College and the School of Pharmacy, University of London. He was awarded the School's silver medals in pharmaceutics, pharmacognosy and pharmaceutical chemistry and immediately commenced the study of chemistry at Birkbeck College. In 1933 he obtained an honours degree in chemistry with distinction and first prize for the course. From 1933-40 he was successively demonstrator and lecturer at the School of Pharmacy, from which Institution he took his Ph.D. in 1941 under the supervision of Prof. Linnell. Hartley helped supervise the evacuation of the School to Cardiff and then in 1940 joined Organon Laboratories, Ltd., as chief chemist and factory manager. From 1943-46 he was secretary to the Therapeutic Research Corporation and the General Penicillin Committee of the Ministry of Supply. $\mathrm{He}$ assumed his present position as scientific services director of the British Drug Houses in 1946. Dr. Hartley is well known in pharmaceutical circles. He has been chairman of the British Pharmaceutical Conference (1957) and is a member of the British Pharmacopoeia Commission Committee. He has also been examiner in pharmaceutical chemistry to the Pharmaceutical Society. His outstanding contributions to the subject were recognized in 1961 by his election to the Sir William Jackson Pope Memorial Lectureship of the Royal Society of Arts. Dr. Hartley has been actively associated for many years with the Royal Institute of Chemistry. He has served many periods as a member of Council and was a vice-president from 1958-60. His numerous friends and associates wish him many years of success in his return to the scene of his earlier triumphs.

\section{Research Committee for Chemical Engineering}

Foncowing publication of the first report of the Exploratory Committee in the April 1962 issue of The Chemical Engineer on the subject of chemical engineering research (see Nature, 195, 209; 1962), the Council of the Institution has now set up a Research Committee under the chairmanship of Dr. J. W. Barrett, director, Monsanto Chemicals, Ltd. The Research Committee will be responsible under the Council for the Institution's activities in encouraging, promoting and guiding research in chemical engineering. Broadly, the objects will be: $(a)$ to help formulate and implement explicit research programmes in fields of chemical engineering in which fundamental research is thought to be required; (b) to help to maintain lively and realistic academic research programmes; (c) to suggest speculative and exploratory fields of research detached from the present-day preoccupations of industry; (d) to make recommendations as to the part which research institutes might play in chemical engineering research. The specific responsibilities of the Committee will include: (1) recommendation to the Council of individuals and topics for industrial research fellowships, guidance of Fellows after their appointment, receipt of their reports and recommendations for action thereon; (2) establishment of working parties and review of the working parties' activities.

\section{U.S. Centre for Advanced Research in Astrophysics}

THE Joint Institute for Laboratory Astrophysics (JILA) has announced a visiting membership programme directed at bringing scientists from throughout the United States and abroad to study at the Institute, which is situated at the University of Colorado in Boulder. The visitors will have complete freedom to work on problems of their own choice for as long as a year. Stipends are available for up to ten scientists during 1963. Visiting memberships are 